\title{
Isolation of environmental microorganisms from clinical specimens: A report of the occurrence of Acinetobacter anitratus in blood of hospitalized patients in Jakarta in a 7 year period
}

\author{
Lucky H. Moehario, Enty Tjoa \\ Department of Microbiology, Faculty of Medicine, University of Indonesia, Jakarta, Indonesia
}

\begin{abstract}
Abstrak
Tujuan Menunjukkan adanya A. anitratus pada isolat klinik (darah) yang berasal dari pasien rawat di rumah sakit di Jakarta selama periode 2002-2008 dan pola sensitivitas mikroorganisme ini terhadap antibiotika.

Metode Penelitian ini merupakan penelitian retrospektif dari semua spesimen darah yang masuk ke Laboratorium Mikrobiologi Klinik Fakultas Kedokteran Universitas Indonesia (LMK-FKUI) dari tahun 2002-2008. Kultur dan pemeriksaan kepekaan terhadap antibiotik dilakukan berdasarkan praktek standar di LMK-FKUI dan Clinical Laboratory Standard Institute pada tahun yang bersangkutan. Data dikumpulkan dengan menggunakan program WHO-NET 5.4. Semua mikroorganisme Gram negative yang diisolasi dari spesimen darah ditabulasi juga termasuk dengan uji kepekaan A. anitratus terhadap antibiotik. Selain itu juga dilakukan analisis terhadap asal spesimen atau dari institusi mana spesimen tersebut berasal.
\end{abstract}

Hasil A. anitratus merupakan bakteri Gram negatif yang paling banyak diisolasi selama tujuh tahun sejak 2002 sampai 2008 dari spesimen darah, dan selalu ditemukan setiap tahunnya. Hampir 50\% bakteri yang diisolasi terdiri dari bakteri tersebut dan Pseudomonas aeruginosa, dan keduanya adalah bakteri lingkungan. Pemeriksaan kepekaan bakteri A. anitratus terhadap antibiotik menunjukkan adanya resistensi terhadap beberapa antibiotik yang diuji. Evaluasi asal spesimen darah menunjukan sebagai berikut: 88 spesimen (74\%) berasal dari Rumah Sakit pemerintah, 18 spesimen (15\%) dari Rumah Sakit swasta, 3 spesimen (3\%) dari pasien praktek dokter dan 10 spesimen (8\%) tidak diketahui asalnya.

Kesimpulan Ditemukan A.anitratus setiap tahun sejak 2002 sampai 2008 dari spesimen darah dari pasien rawat inap di beberapa Rumah Sakit di Jakarta. Diperlukan penelitian lebih lanjut untuk mencari faktor resiko bakteremia A. anitratus agar dapat mengurangi kemungkinan terjadinya infeksi rumah sakit. Selain itu sangat dianjurkan untuk melanjutkan sampai tahap genotyping untuk menentukan hubungan antara strain yang ada di Rumah Sakit dengan strain yang diisolasi dari pasien. (Med J Indones 2009; 18:227-32)

\begin{abstract}
Aim To report the presence of environmental microorganisms, A. anitratus, in blood of hospitalized patients in Jakarta from 2002 to 2008 and their susceptibility to antibiotics.

Methods A Retrospective study w as performed on all blood specimens that were received in Clinical Microbiology Laboratory (CML) Faculty of Medicine University of Indonesia during 2002-2008. Culture and antimicrobial susceptibility examination were carried out according to up to date standard practice in CML and Clinical Laboratory Standard Institute, recpectively. Data was collected by WHONET 5.4 program. All Gram-negative microorganisms that were isolated from blood specimens were tabulated, and so the antibiotics susceptibility of $A$. anitratus. The origin of the specimens in term of institutions where the specimens came from was also analyzed.

Results In a 7 year period up to 2008, A. anitratus was found in blood specimens, and these environmental bacteria were in fact the most predominant isolated Gram negative microorganisms. Together with another environmental microorganism, Pseudomonas aeruginosa, it composed nearly 50\%. Antimicrobial susceptibility test of this microorganism showed some degree of resistance to all tested antibiotics. The origin of those blood specimens which yielded $A$. anitratus were mainly from government-owned hospitals, that was 88 specimens (74\%), followed by private hospitals (18 specimens, 15\%), individuals (3 specimens, 3\%), and unknown source (10 specimens, 8\%).

Conclusion Persistent occurrence of A. anitratus in blood specimens of hospitalized patients in hospitals in Jakarta was observed. In the near future, a study to find risk factors for the acquisition of $A$. anitratus bacteremia is needed to reduce potential hospital associated infection. Moreover, genotyping is advised in order to determine the relationship of hospital and patient derived strains. (Med J Indones 2009; 18:227-32)
\end{abstract}

Key words: gram - negative microorganisms, antimicrobial susceptibility 
The prevalence of Acinetobacter infection has increased worldwide in the past two decades. Centers for Disease Control and Prevention (CDC) and National Nosocomial Infection Surveillance (NNIS) in the United States indicated that Acinetobacter was the cause of $1 \%$ of all nosocomial bloodstream infections, and 3\% of nosocomial pneumonia in US hospitals compared with $5 \%$ to $10 \%$ for Latin America hospitals. ${ }^{1,2}$ In 2008 CDC defined a new terminology 'Health careassociated infection' instead of nosocomial infection. ${ }^{3}$ Acinetobacter species are commensals, pleomorphic aerobic Gramnegativebacilli, and usually coccobacillary or coccal in appearance. This microorganism is able to survive on both moist and dry surfaces and may be part of the normal skin flora of humans. Acinetobacter species are often misinterpreted to be other Gram negative organisms that are more commonly associated with clinical syndromes, e.g. Neisseria meningitidis in cerebrospinal fluid, and Haemophilus influenza in sputum. ${ }^{4,5}$ DNA-DNA hybridization investigations have shown the presence of 25 DNA homology groups that were called genomospecies among Acinetobacter strains. For clinical purposes, 2 phenotypic groups were determined i.e. non hemolytic and hemolytic groups. ${ }^{6}$

Acinetobacter usually colonizes patients in the intensive care setting. The bacteria have low virulence but are capable of causing suppurative infection in almost every organ. In patients with Acinetobacter bacteremia, intravenous catheters are almost always the source of infection. In patients with burns or with immune deficiencies, Acinetobacter acts as an opportunistic pathogen and can produce sepsis. Signs and symptoms that occur depend on the involved organ system. ${ }^{7}$ Mortality and morbidity rates are increased in patients who are very ill with multisystem disease, due to their underlying illness rather than the superimposed infection with Acinetobacter. When associated with polymicrobial bacteremia, mortality rate from Acinetobacter bacteremia had been reported $17 \%$ to $46 \%$, especially for those associated with A. baumannii. ${ }^{8,9}$

The ability of Acinetobacter to use a variety of carbon sources via diverse metabolic pathways expands its habitat. The organisms are widely distributed in soil, sewage, water and in the hospital environment. Acinetobacter has been isolated from a variety of foods, hospital air, vaporizer mist, tap water faucets, peritoneal dialysate bath, bedside urinals, wash cloths, angiography catheters, ventilators, laryngoscope, contaminated gloves, duodenoscopes, reused needles, multi dose medications, plasma protein fraction, hospital pillows, and soap dispensers. Some strains recovered from sink basins have been found to be tolerant of soap. ${ }^{10}$ Acinetobacter has been grown from numerous human sources, including skin, sputum, urine, feces and vaginal secretions. Up to $25 \%$ of healthy adults exhibit cutaneous colonization and $7 \%$ of adults and infants have transient pharyngeal colonization. ${ }^{4}$ Residency in an Intensive Care Unit (ICU), particularly in the presence of other patients who are colonized with Acinetobacter, predisposes to colonization. ${ }^{7}$ Several studies concerning Acinetobacter sp. in critical clinical settings had been conducted in Indonesia. Investigation on Ventilator Associated Pneumonia (VAP) patients hospitalized in National General Hospital Cipto Mangunkusumo in Jakarta in 2006-2007 demonstrated that A. anitratus (32.4\%) was the most Gram negative bacteria that was isolated from lower respiratory secretion, followed by Pseudomonas aeruginosa (P. aeruginosa) (24.7\%), Klebsiella pneumonia (10.4\%), and Methicillin Resistant Staphylococcus aureus (2.6\%). ${ }^{11}$ In 2005, a study was carried out in Burn Unit of the above mentioned hospital and antibiogram similarity suggested an association between Acinetobacter sp. isolated from skin of patients in Burn Unit and those from environment. ${ }^{12}$

This study aimed to report the presence of environmental microorganism, A. anitratus, in blood specimens of hospitalized patients in Jakarta and its proximity during 2002-2008 and their susceptibility to antibiotics.

\section{METHODS}

A retrospective study was performed on all blood specimens received in Clinical Microbiology Laboratory (CML) of Department of Microbiology, Faculty of Medicine University of Indonesia (FMUI) from 2002 to 2008. Culture and identification procedures were carried out according to standard operating procedure in CML FMUI. ${ }^{13,}$

${ }^{14}$ Susceptibility to antimicrobials was determined as in Clinical and Laboratory Standards Institute (CLSI). ${ }^{15}$ Data was collected from WHONET, ${ }^{5.4}$ a computer program that was designed for recording and analyzing microbiology data. All isolated Gram negative organisms from blood specimens, from 1 January 2002 up to 31 December 2008 and susceptibility of $A$. anitratus to antibiotics were tabulated by years. Origin of specimens in term of institutions where the specimens came from was also analyzed.

\section{RESULTS}

Among ten most frequent Gram negative microorganisms that were found in blood specimens during 2002-2008 in Jakarta, $A$. anitratus was the most predominant bacteria with a total of 119 isolates (28\%) out of 432 total isolates. 
Figure 1 shows the presence of $A$. anitratus every year, where the result of the year 2005 seemed to be the lowest (14\%), and 2003 was the highest (34\%). The ten Gram negative bacteria isolated during this 7 year period were as follow: A. anitratus (28\%), P. aeruginosa (21\%), Klebsiella pneumonia (16\%), Enterobacter aerogenes (9\%), Salmonella typhi (8\%), Escherichia coli (7\%), Alkaligenes faecalis (6\%), Klebsiella oxytoca (3\%), and the last two were Enterobacter gergoviae and Klebsiella ozanae (each was 2\%) (see Figure 2). Interestingly, environmental microorganisms such $A$. anitratus and Pseudomonas aeruginosa composed nearly $50 \%$ of the clinical isolates during this period, despite these two bacteria were vastly related to nosocomial infections.

Close examination of the origin of the specimens showed that the specimens came from hospitals and individuals. Of those yielded $A$. anitratus derived

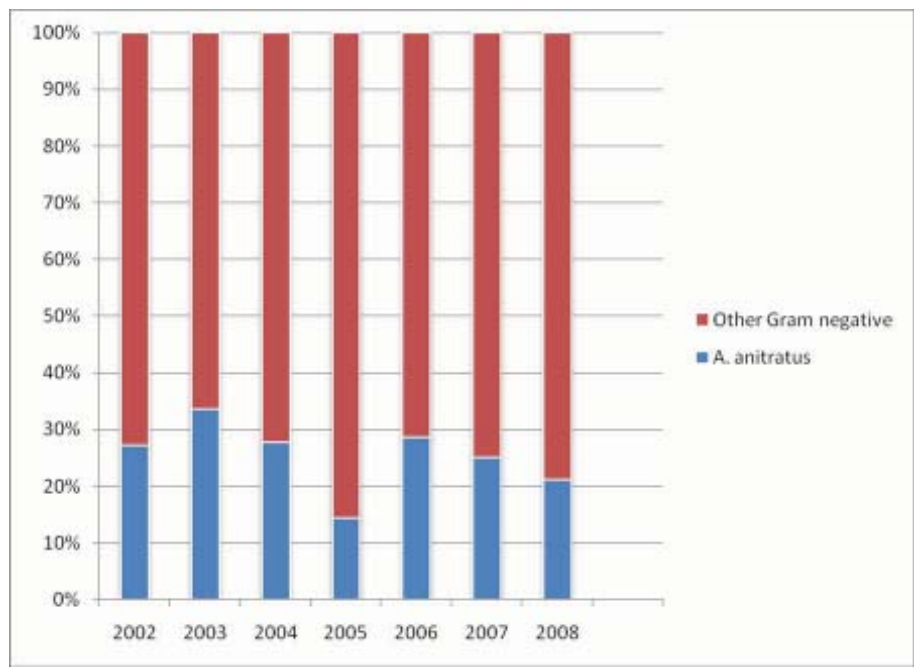

Figure 1. Percentage of isolated Acinetobacter anitratus compared to other Gram negative bacteria

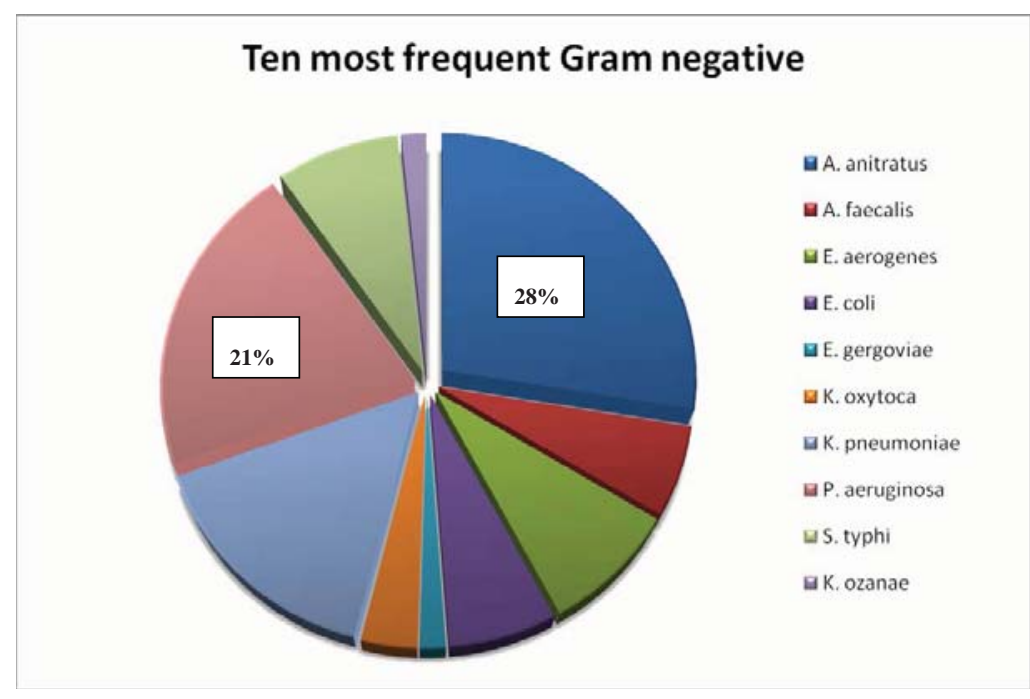

Figure 2. Ten most frequent Gram negative bacteria from blood specimens (2002-2008)

Most environmental microorganisms isolated from blood specimens: A. anitratus (28\%) and P. aeruginosa (21\%). Both composed nearly $50 \%$ of blood specimen isolates. 
mainly from government-owned hospitals, that was 88 specimens (74\%), followed by private hospitals (18 specimens, 15\%), individuals (3 specimens, 3\%), and unknown source (10 specimens, 8\%). The specimens from government-owned hospitals mostly derived from adults in-patient (58\%), followed by neonate and children in-patients (25\%), while ICU patients, adults and neonates/children in emergency room (ER) contributed $10 \%, 2 \%$, and $5 \%$ respectively (Table 1 ).
Susceptibility of A. anitratus to antimicrobials recommended by $\mathrm{CLSI}^{15}$ was shown in Figure 3. To most antimicrobial tested, A. anitratus was showing some degree of resistance. However, the bacteria showed $80 \%$ or greater susceptibility to antimicrobials as follows: Tazobactam-Piperacillin (TZP) 100\%, Cefepime (FEP) 91\%, Meropenem (MEM) 89\%, Levofloxacin (LVX) 83\%, Gatifloxacin (GAT) 100\%, and Sulfamethoxazole (SXT) 89\% (Figure 3).

Table 1. Origin of A. anitratus isolates

\begin{tabular}{|c|c|c|c|c|c|c|}
\hline Origin & Total Specimens & ICU & $\begin{array}{c}\text { In } \\
\text { Adults }\end{array}$ & $\begin{array}{c}\text { ER } \\
\text { Adults }\end{array}$ & $\begin{array}{l}\text { In Neo- } \\
\text { Child }\end{array}$ & $\begin{array}{c}\text { ER Neo- } \\
\text { Child }\end{array}$ \\
\hline Government Hospitals & $88(74 \%)$ & $9(10 \%)$ & $51(58 \%)$ & $2(2 \%)$ & $22(25 \%)$ & $4(5 \%)$ \\
\hline Private Hospitals & $18(15 \%)$ & $\mathrm{Nk}$ & $\mathrm{Nk}$ & $\mathrm{Nk}$ & $\mathrm{Nk}$ & $\mathrm{Nk}$ \\
\hline Individuals & 3 (3\%) & $\mathrm{Nk}$ & $\mathrm{Nk}$ & $\mathrm{Nk}$ & $\mathrm{Nk}$ & $\mathrm{Nk}$ \\
\hline Unknown & $10(8 \%)$ & $\mathrm{Nk}$ & $\mathrm{Nk}$ & $\mathrm{Nk}$ & $\mathrm{Nk}$ & $\mathrm{Nk}$ \\
\hline
\end{tabular}

In: In-patients; ICU: Intensive care unit; ER: Emergency Room; Nk: Not known

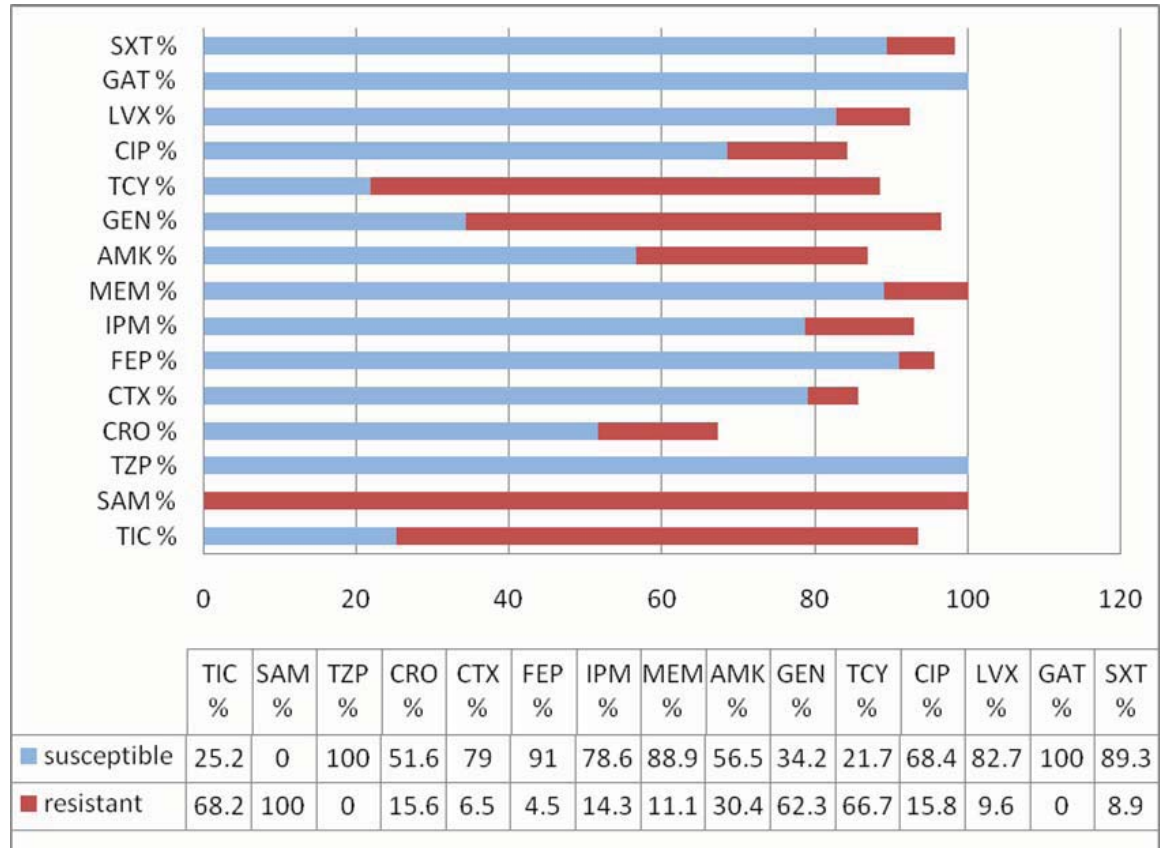

Figure 3. Resistance Patterns of Acinetobacter anitratus to antibiotics (2002-2008)

TIC = Ticarcilin; SAM= Ampicilin-Sulbactam; TZP= Piperacilin-Tazobactam; CRO= Ceftriaxone; CTX= Cefotaxime;

FEP = Cefepime; IPM= Imipenem; MEM= Meropenem; AMK= Amikacin; GEN= Gentamycin; TCY= Tetracycline;

CIP = Ciprofloxacin; LVX= Levofloxacin; GAT= Gatifloxacin; SXT= TrimethoprimSulfamethoxazole. 


\section{DISCUSSIONS}

Persistent discovery of $A$. anitratus in blood specimens during a 7 year period from 2002-2008 from particular hospitals in Jakarta was a strong indication of the existence of the sources of the microorganisms in the hospitals. Moreover, this bacteria and P. aeruginosa composed approximately $50 \%$ of positive clinical isolates during that period. Our finding was in agreement with earlier study which examined VAP patients in hospitals in Jakarta which showed A. anitratus as predominant environmental microorganism in lower respiratory tract. ${ }^{11}$

In Acinetobacter cases, diagnostic is the most problem. The difficulty in diagnosis is mainly in distinguishing between colonization of these bacteria from infection. Generally, colonization means the presence of microorganisms on skin, on mucous membranes, in open wounds, or in excretions or secretions but are not causing adverse clinical signs or symptoms, while inflammation is a tissue response to injury or stimulation that is caused by non infectious agents, such as chemicals and mechanicals, although it can also occur in infection. ${ }^{3}$

Other aerobic Gram negative bacilli such as Enterobacter species, Stenotrophomonas maltophilia, Burkholderia cepacia, P. aeruginosa, Flavobacterium meningosepticum and Seratia marcescens should be considered as differential diagnosis especially in patients with pulmonary infiltrates in ICU, continuous ambulatory peritoneal dialysis (CAPD) associated peritonitis, meningitis, wound infection, or catheter-associated bacteruria. ${ }^{7}$ Pseudo bacteremia resulting from improper specimen collection and blood culture technique should be distinguished from true Acinetobacter bacteremia. Therefore, specimen handling is a very critical step in microbiology examination.

Outbreaks of health care-associated infections due to multi-resistant strains of $A$. anitratus have been reported, and mainly from ICU and surgical intensive care unit. ${ }^{16,17}$ A centre in Netherland performed a case control study, in which risk factors for the acquisition of $A$. anitratus were investigated by comparing epidemiological characteristics of patients who became colonized or infected with those of control patients without colonization. The study showed that ventilators in use were the reservoirs of $A$. anitratus and caused frequent nosocomial respiratory tract infections. ${ }^{18}$ A study in Jakarta in 2006-2007 showed superimposed infection due to $A$. anitratus in patients with mechanical ventilation. ${ }^{11}$ Molecular epidemiology have been carried out in many studies to identify the strain of Acinetobacter sp, in which pulsed-field gel electrophoresis apparently was more discriminative compared to other methods. ${ }^{19-21}$

Acinetobacter strains are often resistant to antimicrobial agents, andtherapyofinfectioncanbedifficult. Ingeneral, first, second, and third-generation of cephalosporins, macrolides, and penicillins have little or no antiAcinetobacter activity, and their use may predispose to Acinetobacter colonization. ${ }^{7,22}$ Overall, there is a trend of increasing resistance of Acinetobacter. However, there are significant differences in Acinetobacter antimicrobial resistance patterns according to species, country of isolation and region. ${ }^{23}$ The current approach to treat a serious infection involving Acinetobacter is based on sensitivity of the specific isolate and the use of combination therapy. In the event of hospital outbreak that involve multidrug-resistant Acinetobacter strains with similar antibiogram, a review of infection control procedures including hand washing, patient isolation, ventilator care, and housekeeping should be carried out.

In conclusion, the occurrence of $A$. anitratus in blood specimens of patients in hospitals in Jakarta was observed persistently from 2002 to 2008. This microorganism showed resistance in some degree to most antibiotic tested except for Piperacilin-Tazobactam (TZP) and Gatifloxacin (GAT). Further study to find risk factors for A. anitratus bacteremia is needed to reduce potential hospital associated infection. In addition, molecular approaches are adviced to be performed, so that the strains (genotypes) of $A$. anitratus can be determined, and the relationship of hospital and patient derived strains can be elucidated.

\section{Acknowledgements}

We thanked A. Kiranasari and I. Ningsih of the Dept. of Microbiology University of Indonesia for their technical assistance.

\section{REFERENCES}

1. National Nosocomial Infection Surveillance (NNIS) System report: Data summary from October 1986-April 1998. Am J Infect Control. 1998; 26: 522-33.

2. Gales AC, Jones RN, Forward KR. Emerging importance of multidrug-resistant Acinetobacter species and Stenotrophomonas maltophilia as pathogens in seriously ill patients: Geographic patterns, epidemiological features and trend in the Sentry antimicrobial surveillance program (1997-1999). Clin Infect Dis. 2001; 32 (Suppl 2): 104-13.

3. Horan TC, Andrus M, Dudeck MA. CDC/NHSN sureveillance definition of health-care associated infection and 
criteria for specific types of infections in the acute care setting. Am J Infect Control. 2008; 36: 309-32.

4. Allen DM, Hartman BJ. Acinetobacter species. In: Mandell GL, Bennett JE, Dolin R, editors. Principles and practice of infectious diseases. $6^{\text {th }}$ edition. Philadelphia: Elsevier; 2005. p.2632-5.

5. Gantz NM, Brown RB, Berk SL, Myers JW. Laboratory report of Gram negative rod in the blood. In: Manual of clinical problems in infectious disease. $5^{\text {th }}$ edition. Philadelphia: Lippincott Williaaams \& Wilkins; 2006: p.433-6.

6. Paul C, Schrecken B, Daneshvar MI, Hollis DG. Acinetobacter, Achromobacter, Chryseobacterium, Moraxella and other nonfermentative Gram negative rods. In: Murray PR, Baron EJ, Jargensen JH, Landry ML, Pfaler MA, editors. Manual of clinical microbiology. $9^{\text {th }}$ edition. Washington: ASM Press; 2007. p770-802.

7. Cunha BA. Acinetobacter. Updated Aug 1, 2008. [Cited 2009 June 8]. Available from: Http://emedicine.medscape. com/article/236891-overview

8. Scerpella EG, Wanger AR, Armitige L. Nosocomial outbreak caused by multi-resistant clone of Acinetobacter baumannii: Results of the case control and molecular epidemiologic investigation. Infect Control Hosp Epidemiol. 1995; 16: 92-7.

9. Wisplinghoff $\mathrm{H}$, Edmond $\mathrm{MB}$, Pfaller MA, Jones RN, Wenzel RP, Seifert H. Nosocomial bloodstream infections caused by Acinetobacter species in United States hospitals: clinical features, molecular epidemiology, and antimicrobial susceptibility. Clin Infect Dis. 2000; 31(3): 690-7.

10. Villegas MV, Hartstein AI. Acinetobacter outbreaks, 19772000. Infect Control Hosp Epidemiol. 2003; 24: 284-95.

11. Saharman YR. Oropharynx and environmental bacteria as the cause of Ventilator Associated Pneumonia (VAP) in ICU/ HCU of National General Hospital Cipto Mangunkusumo [Thesis]. Jakarta: Faculty of Medicine university of Indonesia; 2008.

12. Wiwing S. Roles of environmental microorganism in hospital infection in Burn Unit in National General Hospital Cipto Mangunkusumo [Thesis]. Jakarta: Faculty of Medicine University of Indonesia; 2005.

13. Laboratory of Microbiology of Department Microbiology, Fac. of Medicine Univ. of Indonesia. Standard operating procedure for clinical microbiology examination. Jakarta: FMUI; 1999.

14. Laboratory of Microbiology of Department Microbiology, Fac. of Medicine, Univ. of Indonesia. Standard operating procedure for clinical microbiology examination. Jakarta: FMUI; 2004.

15. Clinical and Laboratory Standards Institute (Formerly NCCLS), Biomerieux Inc. Performance standards for antimicrobial susceptibility testing; twelfth -eighteenth informational supplement. Pennsylvania: Biomerieux; 2002-2008.

16. Bergogne-Berezin E. The increasing significance of outbreaks of Acinetobacter spp.: the need for control and new agents. Available on line May 18, 2004. [Cited 2009 August 10]. Available from: Http://www.science direct. com/science.

17. Cisneros JM, Rodriquez-Bano J. Nosocomial bacteremia due to Acinetobacter baumannii: epidemiology, clinical features and treatment. Clin Microbiol Infect. 2002; 8(11): 687-93.

18. Vandenbroucke-Grauls CMJE, Kerver AJH, Rommes JH, Jansen R, den Dekker C, Verhoef J. Endemic Acinetobacter anitratus in a urgical intensive care unit: Mechanical ventilators as reservoir. Eur J Clin Microbiol Infect Dis. 1988; 7: 485-9.

19. Wisplinghoff H, Seifert H. Molecular epidemiology of Acinetobacter species. In: Bergogne-Berezine, editor. Acinetobacter biology and pathogenesis. New York: Springer; 2009: p1-23.

20. Koeleman JGM, Stoof J, Biesmans DJ, Savelkoul PHM, Vandenbroucke-Grauls CMJE. Comparison of amplified ribosomal DNA restriction analysis, random amplified polymorphic DNA analysis, and amplified fragment lenght polymorphisms fingerprinting for identification of Acinetobacter baumannii. J Clin Microbiol. 2004; 36 (9): 2522-9

21. Erika MC, Agata D, Venkataraman L, DeGirolami P, Samore M. Molecular epidemiology of Ceftazidime-resistant Gram-negative bacilli on inanimate surfaces and their role in cross-transmission during non outbreak periods. J Cli Microbiol. 1999; 37(9): 3065-7.

22. Marchaim D, Navon-Venezia S, Schwartz D, Tarabeia J, Fefer I, Schwater MJ, et al. Surveillance cultures and duration of carriage of multidrug-resistance Acinetobacter baumannii. J Clin Microbiol. 2007; 45(5): 1551-5.

23. Jeena P, Thompson E, Nchabeleng M, Sturm A. Emergence of multi-drug-resistant Acinetobacter anitratus species in neonatal and pediatric intensive care units in a developing country: concern about antimicrobial policies. Annals of Trop Paediatrics. 2001; 21: 245-51. 